CHAPTER 13

\title{
The Italians and the IWMA
}

\author{
Carl Levy
}

\section{Introduction}

Italians played a significant and multi-dimensional role in the birth, evolution and death of the First International, and indeed in its multifarious afterlives: the International Working Men's Association (IWMA) has also served as a milestone or foundation event for histories of Italian anarchism, syndicalism, socialism and communism. ${ }^{1}$ The Italian presence was felt simultaneously at the national, international and transnational levels from 1864 onwards. In this chapter I will first present a brief synoptic overview of the history of the IWMA (in its varied forms) in Italy and abroad from 1864 to 1881 . I will then examine interpretations of aspects of Italian Internationalism: Mazzinian Republicanism and the origins of anarchism, the Italians, Bakunin and interactions with Marx and his ideas, the theory and practice of propaganda by the deed and the rise of a third-way socialism neither fully reformist nor revolutionary, neither Marxist nor anarchist. This chapter will also include some brief words on the sociology and geography of Italian Internationalism and a discussion of newer approaches that transcend the rather stale polemics between partisans of a Marxist or anarchist reading of Italian Internationalism and incorporates themes that have enlivened the study of the Risorgimento, namely, State responses to the International, the role of transnationalism, romanticism,

1 The best overviews of the IWMA in Italy are: Pier Carlo Masini, La Federazione Italiana dell'Associazione Internazionale dei Lavoratori. Atti ufficiali 1871-1880 (atti congressuali; indirizzi, proclaim, manifesti) (Milan, 1966); Pier Carlo Masini, Storia degli Anarchici Italiani da Bakunin a Malatesta, (Milan, (1969) 1974); Nunzio Pernicone, Italian Anarchism 1864-1892 (Princeton, 1993); Renato Zangheri, Storia del socialismo italiano. Volume primo Dalla rivoluzione francese a Andrea Costa (Turin, 1993); Piero Carlo Masini, "La Prima Internazionale", in Pier Carlo Masini and Maurizio Antonioli, Il sole dell'avvenire. L'anarchismo in Italia dale origini all Prima Gurra Mondiale (Pisa, 1999). Useful for its statistics is, Emilio Gianni, L'Internazionale italiana fra libertari ed evoluzionisti. I congress della Federazione Italiana e della Federazione Alta Italia dell'Associazione Internazionale dei lavoratori, 1872-1880 (Naples, 2008); Pier Carlo Masini (ed.), Epistolario inedito dell'Internazionale. La Carte della Commissione di Corrispondenza dall'Archivio della Federazione Internazionale dei Lavoratori (1872-1874) (Milan, (1966) 2013). 
feminism and the politics of generational friendship and the afterlives of the International.

\section{Prehistory and Historical Overview}

The prehistory of the First International can be traced back to three sources. Growing national trade union organisations (largely in north western Europe) and their need to create policies to coordinate the movement of labour across borders and transnational solidarity during strikes, diasporic communities of refugees from the social and national struggles of 1848 and after, and the development of cosmopolitan radical, communist and proto-anarchist secret societies, brotherhoods and clubs. ${ }^{2}$ The Italians in the 1860 s are largely absent from the first type of organisation, but they are present particularly in the nationalist groups which do in fact shade into formations that preach cooperation and cross-class forms of mutuality and education. The central figure of course is Giuseppe Mazzini but the earlier influences of the more radical and class oriented Buonarrotti cannot be discounted if one recalls this previous influence on Chartist circles in London and elsewhere. Mazzini and several other associates were prominent in the initial discussions which eventually led to the First International. But even if Mazzini and his circle were quickly marginalised from the IWMA by Marx and his colleagues, the influence of Mazzinian concepts remained strong in the big battalions of the British trade unions, which never renounced his self-help, cooperative and educational approaches and amongst the most radical fringes of the British trade union movement. Mazzini remained a towering figure even after his negative reaction to the Paris Commune of 1871 . Giuseppe Garibaldi was also a strong influence on the milieu in which the International grew at its London centre in 1864-1865. Although Garibaldi's ideology was always quite indeterminate, his visit to London during April 1864 produced the greatest public demonstration until the protest against British intervention in the Iraq War in 2003 and supercharged the growing proletarian and middleclass radicalism of London in which the infant International's centre grew. ${ }^{3}$

2 Recent overviews: Mathieu Léonard, L'émancipation des travailleurs. Une histoire de la Première Internationale (Paris, 2011); Marcello Musto (ed.), Workers Unite! The International 150 Years Later (London, 2014); René Berthier, La Fin de La Première Internationale (Paris, 2015); Robert Graham, We Do Not Fear Anarchy-We Invoke It. The First International and the Origins of the Anarchist Movement (Oakland, 2015).

3 An excellent recent summary is to be found in Enrico Verdecchia, Londra dei cospiratori. L'esilio londinese dei padri del Risorgimento (Milan, 2010). 
In Italy, the first section (1869) of the IWMA and the centre of activity for Internationalism in the peninsula for the first years of its life were in Naples, albeit an early presence was noted in Sicily, however this would shift to what became the heartland of Italian anarchism and socialism before the Fascist Regime and indeed the heart and soul of twentieth century communism and its successors in the twenty first century: Tuscany, Emilia Romagna, the Marches and slightly later in Lazio and Liguria.

The Italian IWMA had a short but eventful life. Its first national conference was held in Rimini in 1872 and this was followed by national conferences in Bologna (1873), the half- clandestine gathering in Florence-Tosi (1876), Pisa (1878) and on within the Swiss border in 1880 (Chiasso) when the IWMA had already been effectively illegalised earlier in the year, albeit its organisation has already been depleted and disrupted by a series of arrests in the previous years. Besides regional and local congresses, the reformist strand of Italian Internationalism had an initial appearance in Swiss exile in the Ceresio (near Lugano) section of 1875 and a formal congress in Milan in 1877 which saw the foundation of the Federation of Upper Italy that can be characterised by its Milan-Mantua axis.

The most notable growth of the International occurred in the wake of the Paris Commune from 1871 to 1874 when sections and regional federations created a dense web of members and sympathisers: the formal membership reached $32,45^{\circ}$ in the spring of $1874,{ }^{4}$ and it has been argued sympathisers (too cautious to join due to State and employer surveillance) gave it an effective following several times the declared figures. In the small to medium sized towns of Tuscany and the Romagna, the International was a force to be reckoned with, as Naples and Sicily lost their initial predominance, on the other hand later in the 1870s, the Federation of Upper Italy gained a following in the industrialising environments of Milan, Biella and more marginally in Turin and announced the signal role of the countryside for socialism in the Po Valley, with a nuclei of braccianti (landless labourers) in the surrounds of Mantua. ${ }^{5}$ Several historians have argued that the International was the first true political party in Italy as opposed to the personal clan-like followings of the Republicans and the consortia of the Historic Right and Historic Left. And even if one is cautious and argues that it was a type of proto-political party, its membership in the florid early 1870 s, exceeded the membership of the Italian Socialist Party in 1914.

4 Franco della Peruta, "La consistenza numerica dell'Internazionale in Italia nel 1874", Movimento Operaio, 2,3-4 Dicember 1949-1950, pp. 104-106; Nunzio Pernicone, Italian Anarchism 1864-1892 (Princeton, 1993), pp. 75-76.

5 Most notably Pier Carlo Masini and Nunzio Pernicone. 


\section{The Italians and the Schism in the IWMA}

The Italian IWMA played an important role in the schism between so-called authoritarian and anti-authoritarian wings in $1871-1872$ and this leads us to the vexed question of the role of Bakunin in the formation of the Italian International. While it is has been shown that Carlo Pisacane, the federalist socialist hero of the Risorgimento, was not an indigenous source of libertarian socialism or anarchism, it is also the case that Bakunin did not singlehandedly "convert" the Italians to his form of anarchist collectivism, because his anarchism was only formed during his sojourn in Italy in the 1860 os. ${ }^{6}$ For all intents and purposes until the late 1860s, Bakunin was a radical Hegelian "Forty-Eighter" in which the springtime of the peoples was still equated with national revolts with a social tint. But the failure of the Polish rising of 1863 (and indeed its lack of a peasant strategy), Bakunin's interaction with Russian Populists and his sojourns in Italy, drove him to articulate his own form of anarchism, which naturally also had to do with the lasting effects of his earlier encounters with Proudhon in the 1840 s and in $1863 .{ }^{7}$ His attempts to convert the Florentine Free Masonry in 1864 and 1865 or the Genevan Congress of the League for Peace and Liberty (1868) in a revolutionary direction, were dismal failures but his encounters with Left-wing Mazzinians in Naples gave him interlocutors who stimulated his leap into an anarchist politics, but it did not mean that the old method of engaging in a two-level form of politics (secret organisations of initiates and broader organisations tapping the spontaneous passions of the masses) were ever superseded, indeed as is well known one of the reasons for the expulsion of Bakunin from the London Council based International was the argument that he carried his Brotherhood into the International itself. The first generation of Internationalists, such as the representative Giuseppe Fanelli, were veterans of the struggles of the Risorgimento and some like Fanelli were members of the failed expedition to Sapri in 1857 when Pisacane lost his life. ${ }^{8}$ But it appears the case that the openly libertarian socialist aspects of his thought were obscured whereas his direct action politics, his discussion of guerrilla warfare and his Italian patriotism were known. This is not to say that general knowledge of Proudhon's themes (filtered through the work of Giuseppe Ferrari) was absent from the lives of this first circle who associated with Bakunin in Naples. The important point is that even if they were associated with the Mazzinian and

6 T.R. Ravindranathan, Bakunin and the Italians (Kingston [etc.], 1988).

7 Mark Leier, Bakunin. A Biography (New York, 2006).

8 For the latest scholarship on Pisacane see, Carmine Pinto and Luigi Rossi (eds.), Tra pensiero e azione: una biografica politica di Carlo Pisacane (Salerno, 2010). 
Garibaldian quests to force the Kingdom of Italy's hand and conquer Rome (from Aspromonte in 1862 to Mentana in 1867), they were federalists rather than centralisers and they were Free-Thinking atheists, not deists like Mazzini; and unlike Garibaldi, who had donned the Royal uniform and remained equivocal about the new Kingdom of Italy in the 186 os and 1870 , by the late 1860 s they were unequivocally against the Savoy regime, many deeply humiliated by the performance of the Italian state in the War of 1866 . So one can say the development of a libertarian socialism in Italy was a mutually interactive process between Bakunin and his Italian friends.

However, the watershed for the development of the International was the Paris Commune of 1871 . It impacted on Italian politics in several ways. It allowed Bakunin openly to denounce Mazzini for his unbridled attacks on the class-based and atheist politics of the Commune. Secondly many of the future Internationalists had joined Garibaldi's expedition to the Vosges to fight the Prussian invasion of France and then joined the Commune as combatants and suffered death or exile to New Caledonia or more fortunately to Brussels, London, Cairo or elsewhere. ${ }^{9}$ Thus one can point to the example of Amilcare Cipriani, Garibaldian, "Colonel of the Paris Commune" and later unclassifiable anarchist leaning subversive; jailbird in the 1880 os. $^{10}$ But the Commune also clarified the meaning of republicanism, in the wake of the bloody massacre that the Republicans carried out to break the resistance in Paris in May 1871. The Commune was an example of the cell for a future socialist libertarian federation of the French or for that matter for the city-state culture of Italy and the communalist federalist republican movement in Spain. ${ }^{11}$ It is also quite true that later in life some Internationalists, such as the youthful Errico Malatesta, would criticise the failings of the Commune: the lack of a policy to spread the movement beyond Paris, the dominance of Blanquists and the formation of a Committee of Public Safety, the need to promote more direct democracy, and the timidity of its social policy. ${ }^{12}$ Nevertheless the Commune became a litmus test for the European extreme Left and its identification by the powers to be with the International boosted its prestige amongst the radical federalist

For the First International see, Eva Civolani, L'Anarchismo dopo la Comune. I casi italiano e spagnolo (Milan, 1981).

10 Carl Levy, "Italian Anarchism, 1870-1926", in David Goodway (ed.), For Anarchism. History, Theory, and Practice, (London, 1989) see especially, pp. 42-43.

11 Eva Civolani covers this well (see footnote 8) and also see the recent, very interesting global treatment by Kristin Ross, Communal Luxury. The Political Imaginary of the Paris Commune (London, 2015).

12 Errico Malatesta, "La Comune di Parigi e gli anarchici", La Settimana Sangiunosa, London, 18 March 1903. 
republicans in such countries as Italy and Spain. March 18th, the date of the proclamation of the Commune, became a day of commemoration for the Internationalists and for the anarchists until the First World War.

Mazzini was therefore denounced by Bakunin and Garibaldi, but once Mazzini had lost his left-wing to the rapidly growing International, Bakunin could then turn his guns on the inconsistent Garibaldi who failed to seize the initiative in the $1870 \mathrm{os}$ and whose attraction to temporary military dictatorship and ambiguous relationship to the Savoy dynasty confused or alienated his erstwhile supporters. But it must be said that divorce from the political culture of Mazzinianism and Garibaldianism was never complete. One sees it in the ethical drive of republicanism, the importance of addressing the institutional question (Monarchy versus Republic) and the open-hearted rather unfocussed support for Garibaldian-style international solidarity expeditions to fight in wars of national liberation or against reactionaries which harked back to the Liberal International of the period $1815^{-1848}$ and was engrained in the historical genetic code of the Risorgimento and Post-Risorgimento generations. This meant that the watershed of 1871 was far less obvious than was formerly argued by historians. Even an Internationalist, turned firm and lifelong anarcho-communist such as Errico Malatesta who wrote rather damning obituaries on the deaths of Mazzini and Garibaldi, could still participate in Garibalidian flavoured interventions in Bosnia (1876) and Egypt (1882), and Malatesta remained in a life-long conversation and on/off alliance building with Italian Republicans and the followers of Garibaldi's descendants and his legacy to the $1920{ }^{13}$

The last and perhaps most important effect of the Commune was the coming of age of a new generation of radicals, born in the late 1840 s or 1850 s who were for the most part too young to have experienced the struggles of the Risorgimento but were shaped by their profound disappointment for the Kingdom of Italy in the 186os. Thus Carlo Cafiero, Andrea Costa, Errico Malatesta. Emilio Covelli and many other middle-class and aristocratic educated youth, were inspired by the Commune and the Russian Populists, with Bakunin being a radical if older exemplar within their midst. Bakunin served as the charismatic and intellectual catalyst for their conversion, and conversion is an accurate description of many of these idealist youth who abandoned their

13 For legacies of Garibaldi and Mazzini see, Eva Cecchinato, Camicie rosse. I garibalidini dall'Unità alla grande Guerra (Bari, 2007); Christopher Bayly and Eugenio Biagini (eds.), Giuseppe Mazzini and the Globalization of Democratic Nationalism, 1830-1920 (Oxford, 2008). For Malatesta see Carl Levy, The Rooted Cosmopolitan; Errico Malatesta, the Life and Times of an Anarchist In Exile, forthcoming. 
university educations to learn a trade and go to the people (Malatesta) and use their inherited wealth (Cafiero and Covelli) to fund the activities of the International. It was the youthful levy of the early 1870 s that organised the rapid expansion of the International between 1871 and 1874 . These educated youth were neither, as Engels famously wrote, unemployed and unemployable déclassés or in Italian spostati (misfits) but autospostati, the functional equivalent of the Russian narodniks, intellectual and articulate students and graduates with every potential to follow professional careers or indeed if they wished join the former followers of Mazzini and Garibaldi, Giovanni Nicotera or even Francesco Crispi (the current and future nemeses of the Internationalists and the anarchists) in the political ruling classes of post-Risorgimento Italy. ${ }^{14}$

\section{The Italians, Bakunin, Marx and Engels}

But this does not mean that the young and older Italian Internationalists were unthinking followers of Bakunin. It is quite true that Fanelli served as Bakunin's envoy in Spain, but the Internationalists kept their own counsel. Even if they sided with Bakunin and an assortment of anti-authoritarian critics of the London Council they did not attend the momentous Hague Congress and at their Rimini Congress (1872) had already foreshadowed the formal schism of St Imier, albeit given the lack of attendance to bureaucratic detail Engels' claim that they were never registered with the London Council and thus not formal members of the IWMA is probably correct. While Bakunin maintained his collectivism and had harsh words for communism, the Italians were some of the first, if not the first, anti-authoritarians to promote the concept of anarchocommunism. In the wake of Bakunin's death, the young Malatesta, who had met the Russian a few years earlier on what seemed to be his own deathbed, declared publicly that the Italian Internationalists respected his memory but would not like to identify themselves as Bakuninists. ${ }^{15}$ There was the delicate matter of the squandering of Cafiero's inheritance on La Baronata but also Malatesta recalled in 1889 , that the major problem of the International was the personalization of political struggle within the International between self-declared Marxists and Bakuninists when in fact the vast rank and file were neither and the whole exercise had smacked of elitist politics of which socalled anti-authoritarians were not innocent. In short the effect of Bakunin was to solidify an anti-authoritarian federalist current in Italian Internationalism

\footnotetext{
14 See Nunzio Pernicone, Italian Anarchism 1864-1872 (Princeton, 1993), pp. 77-79.

15 Vernon Richards, “Some Notes on Malatesta and Bakunin”, The Raven, 1 (1987), p. 41.
} 
which was further exacerbated by what was seen from the peninsula as the underhanded, rude and dictatorial policies emanating from the London Council. 16

The relationship of this group to Marx and Engels and colleagues in London was not as clear-cut as one would imagine. Marx and Engels were impressed by the young Cafiero when he visited them in London in 1870-1871 and indeed he became one of their chief enthusiastic correspondents from Italy. Then, the relationship soured after Cafiero read the Communist Manifesto and was particularly horrified and bemused about the "dictatorship of the proletariat" and the future agricultural armies envisaged during the period of socialist transition. He expressed scepticism when he thought about the rather rebellious peasantry of the Mezzogiorno who had avoided the conscription agents of the new Kingdom of Italy. And of course Bakunin, himself, had been appointed an agent to fight off Mazzini and his influence in Italy until their brief reconciliation disintegrated. It has been argued that Engels neglected Italy and thus the "Bakuninists" could carry out their "nefarious work", ${ }^{17}$ but it is curious that the spread of Marx's theoretical work in this period and indeed for many years after, was the result of Covelli's dissemination of Marx's writing on political economy and later the rendering into Italian of Das Kapital by Cafiero years after his disenchantment with Marx and Engels. ${ }^{18}$ The Internationalists disagreed with the leadership of the London Council because of the way it governed the International. They mobilised against Resolution Nine of the special conference of the London IWMA in 1871 which underlined the importance of political and electoral participation of the International. They argued over who were the agents of the revolutionary transformation: the industrial proletariat as argued by the "Marxists" versus the Italian Internationalists who plumped for a coalition of forces in which the peasantry, the poorer sectors of the city population, the artisans and "the workers of thought" had a greater role than the smaller and rather weak factory working class of Italy. Albeit the idea that they thought this tiny but growing stratum was a hopeless case, is mistaken. However, the Internationalists were still highly dependent on the general thrust of Marxian political economy, even as they engaged in invective with the London Council: intellectually they were still in the grip of Marx's brilliance.

16 Davide Turcato, Making Sense of Anarchism: Errico Malatesta's Experiments with Revolution, 1889-19oo (Basingstoke, 2012), pp. 19-20.

17 Pernicone, Italian Anarchism, p. 46.

18 For Carlo Cafiero see the chapter in this volume by Mathieu Léonard. 


\section{Sociological Analysis of the IWMA Membership}

As I have suggested, the membership of the Italian IWMA had a notable group of middle-class and even aristocratic figures in the leadership but the vast majority of Internationalists were artisans (shoemakers, printers, carriage makers, saddle makers, etc.) and labourers such as porters and stevedores, but there were some factory workers, indeed women from the cigarette and cigar factories of Florence and elsewhere were notable participants. Not only was the International the first political party (or proto-party), it was also the first party or political grouping with independent women's sections.

There are hundreds or thousands of working-class women who were active in the International who still deserve their historian, whose history has so far has been limited to biographical treatments of leading figures. ${ }^{19}$ Even if the International began to develop a policy for the countryside, like the Mazzinian Republicanism from which most came from, they had little presence in the rural Po Valley or in the South. On the face of it this seems odd. But unlike the Spanish case where the Internationalist artisans of the small towns and cities of Catalonia and particularly Andalusia spread the movement to rural areas, the timing was less auspicious in the Italian case: the great agricultural depression, pauperization of the countryside, mass migration but also radicalization especially of those who remained in the Po Valley (which also experienced an industrialization of agriculture), led to the mass recruitment of the landless labourers into the pioneer socialist movements and trade unions of the $188 \mathrm{os}$ and 1890 s when the Internationalists were no longer around. Although many landless labourers and other categories in the countryside flirted with syndicalism in the early twentieth century, the anarchists were much more prominent in the former Internationalist smaller to medium-sized towns of central Italy (the Romagna, Tuscany, the Marches etc.).

The working-class or artisanal backbone of the International was sustained by their own Fasci Operai (Workers' Circles), which served as primitive trade union and cultural centres and it should also be said that during the strike waves of the early 1870 s, Internationalists took some part as organisers. But the attitude of many of the more prominent Internationalists was ambiguous: many Internationalists believed in "the iron law of wages" which argued that gains from strikes would inevitably be eaten up by ensuing inflation. And thus the immediate overturning of the capitalist system was the only sensible policy. Also the "workers of thought", as the University of Bologna graduate

19 Elena Bignami, "Le schiave degli schiavi". La "questione femminile" del socialism utpoistico all'anarchismo italiano (1825-1917) (Bolonga, 2011), pp. 75-105; 149-200. 
and star pupil of the great poet Giosuè Carducci, Andrea Costa, put it, were suspicious of what we might call workerist tendencies. ${ }^{20}$ As Malatesta argued, a former medical student who retrained as a mechanic, gas-fitter and later electrician, the revolution was humanist, not for a particular class. So even if the Internationalists criticised Mazzini for his denunciation of the Paris Commune as self-destructive class war, they hadn't moved that far from his position. The working class needed to be organised, that was the aim of Malatesta's rather unsuccessful quest in the Guppy engineering factory in Naples in the early 1870 s, but the revolution the Internationalists were promoting was more inclusive in their eyes than narrow corporate advantage. ${ }^{21}$

\section{Tactics and Ideology of the IWMA in Italy}

Even the Internationalists' firm opposition to Resolution Nine and to electoral politics, was not so extremist in the Italian situation of the $1870 s$. The Mazzinian Republicans had had a strong tradition of electoral abstention during the early days of what they felt was an illegitimate monarchist regime and they were joined by the Catholics ordered by the Pope, at least initially, to boycott the political system of the Pope's "prison warden", and of course disgruntled followers of the Kingdom of Naples had still not recognised the new order. Until the 1880 s the suffrage only encompassed a vanishingly small minority of the adult population, so in these senses the Internationalists were not speaking in a vacuum. That being said, the Internationalists seemed to disregard the fact that Giuseppe Fanelli remained a parliamentary deputy after his conversion to Internationalism and indeed used his free rail travel afforded by his office to spread its gospel. ${ }^{22}$

From 1872 the Internationalists embarked on an insurrectional strategy which harked back to the conspiracies of the Risorgimento and indeed was foreshadowed by Republican insurrectional attempts as late as 1870. With the re-evaluation of the entire corpus of Pisacane's work, the Internationalists envisaged these insurrections as a Social Risorgimento. The first attempt was tried in 1874 and centred on seizing the major towns and cities of central Italy, Rome and in the South, Apulia (Sicily was ignored). This was a disastrous fiasco, the last fling of the ageing Bakunin, and failed to materialize anywhere except in the surrounds of Bologna and here the several hundred conspirators

\footnotetext{
20 Pernicone, Italian Anarchism, pp. 74-75.

21 Turcato, Making Sense of Anarchism, pp. 29-34.

22 Levy, "Italian Anarchism, 1870-1926", pp. 25-29.
} 
were either dispersed or arrested, along with senior Republicans at Villa Ruffi, who had met to prevent followers of their cause from joining. The second attempt was a break from the rather familiar city-based strategy of 1874, because unlike Mazzinian predecessors, with the significant exception of Pisacane's attempt in 1857 , the aim was to raise the countryside in rebellion. As one of the conspirators argued, a social jacquerie was needed in which the peasantry in the villages of Italy seized their lands, destroyed the tax and land title regime of the State and promoted a federation of localities throughout the peninsula. The rugged mountain chain, the Matese, fairly near Naples was chosen, the Russian Populist Sergei Kravchinsky ("Stepniak"), who Malatesta had met during his adventure in Bosnia in 1876, wrote a guerrilla manual for the operation, but once again most of the conspirators were arrested before the plan could be initiated. Most of the remaining small band could not be understood by the dialect-speaking peasants, and when they did seize several villages, the insurrectionists neither had the time nor numbers to establish what in the twentieth-century guerrilla parlance might be termed a foco, a rural soviet or a liberated zone. ${ }^{23}$

The insurrectional strategy was formulated within the context of waves of discontent which had shaken Italy in the 186 os and early 1870 (recall the previously mentioned strikes): Turin rioted in 1864 when the provisional capital was moved to Florence, Palermo had been briefly seized by a coalition of insurgents in 1866, the grist mill tax (the macinato) led to widespread rural rioting throughout peninsula in 1869 and widespread banditry mixed with clerical/ Bourbon guerrilla warfare in the rural hinterland of former Kingdom of Naples. Indeed the Matese was chosen because of its history of anti-regime guerrilla warfare before 1860 and pro-Bourbon guerrilla warfare in the aftermath of the establishment of the Kingdom of Italy. But clearly both urban and rural strategies were a disaster for the Internationalists and used by the government to crush the International and outlaw it by the end of the decade. ${ }^{24}$

The Internationalists had invoked the concept of the propaganda of the deed to explain what the Matese adventure was all about. By this they meant

23 For these two failed risings see, Pier Carlo Masini, Gli Internazionalisti. La Banda del Matese (1876-1878) (Milan-Rome, 1958); Pernicone, Italian Anarchism, pp. 82-128; Luigi Parente (ed.), Movimenti sociali e lotte politiche nell' Italia liberale. Il moto del Matese (Milan, 2001); Giulio de Martino and Vincenza Simeoli, La polveriera d'Italia. Le origini del socialismo nel Regno di Napoli (1799-1877) (Naples, 2004); Bruno Tomasiello, La Banda del Matese 1876-1878, I documenti, le testimonianze, la stampa dell'epoca (Casavelino Scalo, 2009).

24 For an overview of the Mezzogiorno see, Salvatore Lupo, L'unificazione italiana. Mezzogorno, rivoluzione, guerra civile (Rome, 2011). 
either an insurrectional foco which would link up with the "spontaneous" discontent of the peasantry and succeed to establish a base from which a national revolution could be launched or at least a failed attempt would raise the consciousness of the peasantry of the locality for future attempts. But very rapidly the concept was transformed into acts of political assassination, targeted terrorism and finally random acts of terror. Further mutation was in reaction to the change in government policy. In most of the trials arising from the events of 1874 and 1877 the defendants were acquitted by middle-class juries, who may have had little in common with the Internationalists but were swayed by Risorgimento-like eloquence of the young, educated and physically attractive defendants. ${ }^{25}$ Under the Historic Right, the policy of government was to harass and place the International under surveillance. The State was well informed of the plotting before risings of 1874 and 1877 and sort to entrap the conspirators so as to destroy the International. The arrival of the Historic Left in power promised greater liberties, but in fact led to the criminalisation of the Internationalists: they were considered a criminal conspiracy on par with the Mafia and the use of preventive arrest and internal exile became weapons employed against the entire Left from time to time until the early twentieth century. ${ }^{26}$ The reaction of the likes of Covelli and Cafiero was to embrace their "othering" as malfattori (evil-doers) and promote a cult of illegalism and anti-organizational anarchism that greatly weakened the anarchist strand of the defunct International in the 1880 s and found its realization in the pronouncements of the London Congress of social revolutionaries in 1881. This undermined forms of organisational and anti-terrorist anarchism, which Malatesta and kindred organisational anarchists sought to promote in the 1880 s and $1890{ }^{27}$

\section{Conclusion: Decline and Aftermath of the IWMA in Italy}

Attempts on the life of the King by a deranged republican and series of mysterious bomb blasts in the late 1870 s destroyed the national organisation even if local anarchist sub-cultures remained vibrant and sprang back to life in the

25 Pier Carlo Masini, Storia degli anarchici italiani da Bakunin a Malatesta (Milan, (1969) 1974), pp. 91-104; 129-150.

26 Susanna di Corato Tachetti, Anarchici, Governo, Magistrati in Italia 1876-1892 (Turin, 2009), pp. 17-156; Piero Brunello, Storie di Anarchici e di Spie (Rome, 2009); Turcato, Making Sense of Anarchism, pp. 71-126 and in general see, Giampietro Berti, Errico Malatesta e il movimento anarchico italiano e internazionale, 1872-1932 (Milan, 2003).

Pier Carlo Masini, Storia degli anarchici italiani, pp. 166-168. 
1880 and $1890 s$. Attempts to reconstitute the International at Chiasso in 1880 failed as the reformist Federation of Upper Italy could not be reconciled with the anarchists, while many anarchists embarked on diasporic odysseys that at certain times before 1914 meant that the centre of gravity for the Italian anarchists was in the wider world and not Italy itself. ${ }^{28}$

The reformist rivals to the Internationalists found bases in Palermo and Milan but they should not be considered Marx's allies. The politics of Enrico Bignami, Osvaldo Gnocchi-Viani or Benoît Malon (a French exile from the Commune) advanced forms of libertarian gas and water socialism, which drew on a reading of 1871 and were not completely dismissive of Bakunin. In a series of compromises, with electoralism, Andrea Costa broke from his anarchist Internationalist comrades. Attending the "anarchist" international congress in Verviers and the "socialist" international congress at Ghent in September 1877 . Costa remained within the ambit of the Italian IWMA but seemed to be lukewarm about its insurrectional strategy. In the ensuing years he created a series of party devices, which were anchored in the peculiar political culture of the Romagna (the Revolutionary Socialist Party of the Romagna) and reflected a policy that argued for contesting communal elections and parliamentary elections, by exploiting an expanding male electorate to exercise power in the cities and provinces. Thus Costa envisaged a minimum programme in collectivism advanced by electoral means but a maximum goal of anarcho-communism. ${ }^{29}$

There are several fields that still need further study. One might study the leadership and cadre formations of the IWMA through the lenses of romanticism, generational history and friendship circles, as had been done for the Risorgimento. ${ }^{30}$ Further, we now possess the biographical data located in dictionaries to compose a statistical superstructure which might be able to contrast the popular classes with this elite, through comprehensive prosopographical studies. Finally, the popularity of transnational studies of the Risorgimento on the one hand and the post-1870s anarchist movement on the other, still need bridging studies which focus on the origins of Internationalist transnationalism in London, Cairo, Lugano and elsewhere, supplementing earlier works on the movement of Communard exiles to Italy, the exchanges

28 Davide Turcato, "Italian Anarchism as a Transnational Movement, 1885-1915", International Review of Social History, $5^{2}$ (2007), pp. 407-444.

29 Pernicone, Italian Anarchism, pp. 165-168.

30 For an earlier attempt at friendship circles see, Claudia Bassi Angelini, Amore e anarchia. Francesco Pezzi e Luisa Minguzzi, due ravennati nella seconda metà dell'Ottocento (Ravenna, 2004). 
between German Marxists and the Italians, or comparisons between the International in Italy and Spain. ${ }^{31}$

31 For a review of the recent work on the Risorgimento, see Maurizio Isabella, "Rethinking Italy's Nation-Building 150 Years Afterwards: The New Risorgimento Historiography", Past and Present, 217 (2012), p. 268. For some initial suggestions on filling the gap, see Maurizio Binaghi, Addio Lugano bella: gli esuli politici nella Svizzera italiana di fine Ottocento: 1866 1895 (Locarno, 2002); Anthony Gorman, "Diverse in race, religion and nationality ... but united in aspirations of civil progress': the anarchist movement in Egypt 1860-1940", Steven Hirsch and Lucien van der Walt (eds.), Anarchism and Syndicalism in the Colonial and Postcolonial World, 1870-1940 (Leiden, 2014), pp. 3-13; Pietro Di Paola, The Knights Errant of Anarchy. London and the Italian Anarchist Diaspora (1880-1917) (Liverpool, 2013), pp. $1-59$. 